\title{
PKM DESA PINELENG SATU TIMUR KECAMATAN PINELENG KABUPATEN MINAHASA DALAM UPAYA PREVENTIF HIV-AIDS TERHADAP IBU-IBU DAN REMAJA PUTRI DALAM PERSPEKTIF HAK ASASI MANUSIA
}

\author{
Yoan Barbara Runtunuwu
}

\begin{abstract}
ABSTRAK
Sehat adalah keadaan sejahtera seutuhnya baik secara fisis, jiwa maupun sosial, bukan hanya terbebas dari penyakit atau kecacatan. Remaja merupakan kelompok masyarakat yang hampir selalu diasumsikan dalam keadaan sehat. Padahal banyak remaja yang meninggal sebelum waktunya akibat kecelakaan, percobaan bunuh diri, kekerasan, kehamilan yang mengalami komplikasi dan penyakit lainnya yang sebenarnya bisa dicegah atau diobati. Banyak juga penyakit serius akibat perilaku yang dimulai sejak masa remaja contohnya merokok, penyakit menular seksual, penyalahgunaan narkotika, alkohol, psikotropika, dan zat adiktif lainnya (NAPZA), Human Immunodeficiency Virus - Acquired Immunodeficiency Syndrome (HIV-AIDS), kurang gizi, dan kurang berolahraga. Semua ini, yang akan mencetuskan penyakit atau kematian pada usia muda.

HIV yang merupakan singkatan dari Human Immunodefiency Virus adalah Virus Penyebab AIDS. Virus ini menyerang dan merusak sistem kekebalan tubuh manusia sehingga tidak bisa bertahan terhadap penyakit-penyakit yang menyerang tubuh manusia. Ibu-ibu dan Remaja Putri merupakan kaum yang lemah dan memiliki HAM sebagai kelompokyang rentan dan wajib dilindungi oleh Negara dan Hukum. Reproduksi yang hanya ada pada kaum hawa merupakan Hak Asasi selain dijaga juga dilindungi.

Aspek hukum dan HAM merupakan dua komponen yang sangat penting dan ikut berpengaruh terhadap berhasil tidaknya program penanggulangan yang dilaksanakan. Telah diketahui bahwa salah satu sifat utama dari fenomena HIV \& AIDS terletak pada keunikan dalam penularan dan pencegahannya. Berbeda dengan beberapa penyakit menular lainnya yang penularannya dibantu serta dipengaruhi oleh alam sekitar, pada HIV \& AIDS justeru penularan dan pencegahannya berhubungan dengan dan atau tergantung pada perilaku manusia. Diharapkan penegtahuan dan pemahaman terhadap bahaya HIV-AIDS dapat terwujud dan mereka sadar akan pentingnya kesehatan bagi tubuh kita, sehingga pada akhirnya dapat tercapai Indonesia bebas HIV-AIDS.
\end{abstract}

Kata Kunci: HIV-AIDS, Ibu-ibu dan Remaja Putri, Hak Asasi Manusia 


\section{PENDAHULUAN}

Dengan terbitnya Peraturan Presiden nomor 75 tahun 2006 tentang Komisi Penanggulangan AIDS Nasional dan Peraturan Menteri Dalam Negeri nomor 20 tahun 2007 tentang Pedoman Umum Pembentukan Komisi Penanggulangan AIDS dan Pemberdayaan Masyarakat Dalam Rangka Penanggulangann HIV dan AIDS di Daerah maka kedudukan Komisi Penanggulangan AIDS mulai dari tingkat nasional, provinsi sampai ke kabupaten/kota di seluruh Indonesia menjadi semakin kuat untuk memimpin dan mengelola penanggulangan AIDS secara komprehensif, sistematis dan terkoordinasi pada semua tingkatan.Strategi dan Rencana Aksi Nasional (SRAN) Penanggulangan AIDS tahun 20072010 adalah dokumen strategi pertama yang menggunakan perencanaan berbasis biaya. Kemudian, SRAN tahun 2010-2014 yang disusun berdasarkan arahan kebijakan RPJMN 2010-2014, telah digunakan sebagai acuan bagi semua pelaksana penanggulangan AIDS termasuk mitra kerja pembangunan nasional dan internasional. SRAN untuk 5 tahun mendatang, disusun mengacu pada RPJMN 2015-2019, dalam kerangka pembangunan yang berkelanjutan untuk mempertahankan momentum penanggulangan HIV dan AIDS yang sedang bergerak menuju kemandirian pendanaan dan integrasi program ke dalam sistem pemerintah dan masyarakat. Upaya pencegahan dan penanggulangan HIV dan AIDS tidak dapat dipisahkan dari aspek hukum dan hak Asasi manusia (HAM). Permasalahan pokok yang menyangkut hukum berkaitan dengan maraknya kasus HIV/ AIDS adalah bagaimana menyeimbangkan antara perlindungan kepentingan masyarakat dan kepentingan individu pengidap HIV dan penderita AIDS

Aspek hukum dan HAM merupakan dua komponen yang sangat penting dan ikut berpengaruh terhadap berhasil tidaknya program penanggulangan yang dilaksanakan. Telah diketahui bahwa salah satu sifat utama dari fenomena HIV \& AIDS terletak pada keunikan dalam penularan dan pencegahannya. Berbeda dengan beberapa penyakit menular lainnya yang penularannya dibantu serta dipengaruhi oleh alam sekitar, pada HIV \& AIDS justru penularan dan pencegahannya berhubungan dengan dan atau tergantung pada perilaku manusia.
Perilaku manusia selalu bersentuhan dengan hukum dan HAM. Hukum adalah suatu alat dengan dua fungsi utama, yakni sebagai social control dan social engineering. Sebagai social control, hukum dipakai sebagai alat untuk mengontrol perilaku tertentu dalam masyarakat sehingga perilaku tersebut tidak merugikan diri sendiri dan anggota masyarakat lainnya. Sebagai social engineering, hukum dijadikan sebagai alat yang dapat merekayasa sebuah masyarakat sesuai keinginan dan cita-cita hukum

Dalam rangka penyadaran, penegakan dan penanggulangan HIV-AIDS, PKM LPPM Universitas Negeri Manado dalam hal ini saya sebagai pemateri memberikan sosialisasi/penyuluhan di Desa Pineleng Satu Timur Jaga III kepada masyarakat yakni Ibu-ibu dan Remaja putri. Sosilaisasi/penyuluhan disampaikan guna mencapai target eliminasi HIV-AIDS Indonesia bebas HIV pada tahun 2030. Melalui dukungan dari pemerintah desa setempat dan organisasi wanita lainnya membangun kerjsama untuk menyebar informasi pencegahan dan penanggulangan HIV kepada masyarakat.

\section{TARGET LUARAN}

Adapun target luaran adalah hasil penyuluhan yang dilaksanakan tampak pada meningkatkan pengetahuan dan pemahaman masyarakat tentang pencegahan HIV-AIDS.

\section{METODE PELAKSANAAN}

Dalam kegiatan pengabdian pada masyarakat ini adanya teori-teori yang perlu dipahami para peserta. Penyampaian teori tersebut menggunakan metode sebagai berikut:

a. Ceramah

b. Tanya Jawab, dan

Beberapa indikator yang diukur dan dinilai dalam penyuluhan hukum tentang pencegahan HIV-AIDS, meliputi:

a. Kemampuan memahami maksud, tujuan dan sasaran pelaksanaan kegiatan

b. Sikap, apresiasi, nilai-nilai moral

Untuk menyelesaikan permasalahan yang dialami mitra tentang kurangnya pengetahuan tentang Preventif HIV-AIDS dalam Perspektif Hak Asasi Manusia, maka tim menyelenggarakan pengabdian yang terdiri dari tiga tahapan yaitu:

1. Sosialisasi pentingnya pemahaman tentang apa itu HIV-AIDS dan Hak 
Asasi Manusia serta peraturan hukum yang melindungi Hak Wanita dan Anak dalam hal ini ibu-ibu dan remaja putri yang merupakan generasi penerus bangsa;

2. Identifikasi mitra;

3. Monitoring pelaksanaan berdasarkan identifikasi mitra

\section{Metode Pendekatan Pengabdian}

Pada tahapan sosialisasi pentingnya HIV-AIDS dan Hak Asasi Manusia serta peraturan hukum didalamnya, digunakan metode direct instruction dan metode diskusi. Untuk tahapan pengidentifikasian mitra digunakan metode sensus. Sedangkan untuk monitoring pelaksanaan menggunakan observasi langsung maupun tidak langsung dimana tim akan mengadakan pertemuan untuk membahas hasil dan kendala yang ditemui guna untuk perbaikan.

1. Partisipasi Mitra dalam Pelaksanaan Program

Mitra dalam pengabdian ini adalah masyarakat Desa Pineleng Satu Timur, terdiri dari Ibu-ibu dan Remaja Putri di Jaga III. Partisipasi mitra dalam pengabdian pada masyarakat ini adalah menyiapkan sarana dan prasarana yaitu: aula, meja, kursi, sumber listrik, LCD, proyektor, alat tulismenulis masing-masing peserta dan pada tahap pengidentifikasian ibu-ibu dan remaja putri menjadi aktor utama.

2. Evaluasi Pelaksanaan Program dan Rencana Keberlanjutan Program

Evaluasi dilakukan terhadap kegiatan yang telah dilaksanakan adalah sebagai berikut: Evaluasi tahap pertama menggunakan metode diskusi untuk melihat sejauh mana pengetahuan dan pemahaman mitra mengenai Preventif HIV-AIDS dalam Perspektif Hak Asasi Manusia.

Evaluasi tahap kedua adalah menggunakan metode observasi langsung untuk melihat pelaksanaan pengidentifikasian mitra dan monitoring pelaksanaan berdasarkan identifikasi ibuibu dan remaja putri.

Evaluasi tahap ketiga adalah menganalisis kekuatan dan kelemahan yang ditemui dalam pelaksanaan kegiatan pengabdian ini, serta mencari solusi sebagai dasar untuk menentukan rekomendasi terhadap keberlangsungan atau pengembangan kegiatan-kegiatan berikutnya.
Rencana keberlanjutan program dari pengabdian ini kami sebagai mitra akan berusaha menjalin hubungan kerja sama yang baik dengan para peserta penyuluhan/sosialisasi serta bekerjasama dengan Hukum Tua dan Kepala Jaga untuk memantau pelaksanaan program Warga Peduli AIDS (WPA)

Mitra dalam kegiatan ini adalah Desa Pineleng Satu Timur. Masyarakat membutuhkan sosialisasi dan penyuluhan hukum untuk dijadikan pemahaman dasar dengan indikator dan materi penyuluhan/sosialisasi berkaitan mengenai Preventif HIV-AIDS dalam Perspektif Hak Asasi Manusia.

Dalam pelaksanaan kegiatan ini perlu dilakukan evaluasi untuk mengetahui tingkat keberhasilan kegiatan. Adapun aspek yang akan dievaluasi dalam kegiatan ini, yaitu keaktifan mengikuti selama pelaksanaan kegiatan dan pemahaman serta merumuskan tindakantindakan positif yaitu dengan merubah paradigma dan pola pikir untuk menerima mereka yang terinfeksi HIV-AIDS (ODHA) ketika nanti didapati di lingkungan tempat tinggal mereka atau di mana saja.

\section{HASIL DAN PEMBAHASAN HIV/AIDS dan Hak Asasi Manusia}

Di dalam Strategi Nasional Penanggulangan HIV/AIDS, masalah HAM untuk odha (orang dengan HIV/AIDS) telah diatur dengan baik sekali. Namun kenyataan di lapangan - antara lain data ratusan odha yang didukung oleh Yayasan Pelita Ilmu, Jakarta, sejak 1989 - menunjukkan cukup banyak odha yang mendapat perlakuan tidak semestinya. Ada yang dipecat dari pekerjaannya, ada yang diminta mengundurkan diri, ada yang dikucilkan oleh keluarga, oleh masyarakat sekitarnya, ada pula yang ditolak rumah sakit dengan berbagai alasan sewaktu memerlukan rawat inap. Ada juga odha yang status HIV-nya dibuka di media massa, lengkap dengan identitas dan alamatnya, tanpa izin yang bersangkutan. Juga ada odha perempuan yang hamil yang ditolak oleh lingkungannya, sehingga terpaksa pergi ke Jakarta untuk melahirkan karena tidak diperbolehkan melahirkan di desanya ataupun di kota terdekat.

Tantangan terbesar di Indonesia, menurut UNAIDS, adalah diskriminasi dan stigma. Meski kebijakan di tingkat 
nasional sudah ada, namun implementasinya di provinsi dan kabupaten/kota masih jauh dari ideal.

\section{Perlindungan HAM = Pengendalian Epidemi}

Perlindungan HAM bagi odha adalah hal yang esensial untuk menjaga nilai-nilai kemanusiaan kita. Namun di atas itu, perlindungan HAM bagi odha juga penting untuk mendukung program pencegahan dan penanggulangan HIV/AIDS yang efektif. Kepentingan kesehatan masyarakat sebetulnya tidak berlawanan dengan perlindungan HAM untuk odha. Sudah terbukti bahwa bila HAM dilindungi maka odha dan keluarganya dapat hidup tenang, lebih sehat, mempunyai harga diri, mampu menghadapi masalah penyakit HIV/AIDS dengan lebih baik, dan berperilaku sehat sehingga memperkecil risiko penularan.

Untuk menumbuhkan respon yang efektif terhadap epidemi HIV/AIDS dan penghormatan terhadap hak asasi para odha diperlukan perlu keikutsertaan banyak pihak: mulai dari tanggungjawab pemerintah, penerapan reformasi undang-undang, peningkatan upaya dukungan, serta penciptaan lingkungan yang mendukung untuk para odha oleh masyarakat dan pelaku bisnis.

Dalam konteks HIV/AIDS, untuk menghormati norma HAM internasional yang telah kita ratifikasi dan untuk mencapai tujuan kesehatan masyarakat yang pragmatis, pemerintah wajib mempertimbangkan beberapa masalah yang agak kontroversial termasuk masalah prostitusi, narkotika dan homoseksualitas. Merupakan tanggung jawab pemerintah untuk mengidentifikasi cara-cara menegakkan HAM sekaligus melindungi kesehatan masyarakat dengan mempertimbangkan konteks budaya, politik, dan agama. Walaupun tanggung jawab primer tetap di tangan pemerintah, peran LSM-LSM peduli AIDS, odha, serta badan-badan donor juga amat penting dalam hal ini

\section{Hak dan Kewajiban Odha}

Odha berkewajiban menjaga kesehatan diri, keluarga dan lingkungannya dan mencegah penularan HIV dari dirinya ke orang lain. Bila odha pergi ke dokter, dokter gigi, bidan, atau harus dirawat di rumah sakit, ia perlu memberitahukan status HIV-nya. Ada beberapa bentuk hak asasi manusia yang terkait dengan HIV/AIDS yang dapat dikaji. Berbagai hak ini tidak dapat dilihat secara terpisah, melainkan saling berhubungan dan saling mempengaruhi. Untuk aplikasinya perlu dipertimbangkan latar belakang sosial, budaya, sejarah dan agama. Adalah tugas pemerintah dan tugas kita semua, untuk mempromosikan dan melindungi semua hak-hak tersebut. Menurut dokumen WHO tahun 1998 mengenai petunjuk pelaksanaan "HIV/AIDS and Human Rights," ada beberapa hal yang penting diperhatikan menyangkut hak asasi odha:

Pertama, hak atas perlakuan nondiskriminatif termasuk hak atas kedudukan yang sama di depan hukum. Undang-undang internasional mengenai HAM menjamin hak perlindungan hukum dan kebebasan dari segala bentuk diskriminasi, baik yang berdasarkan warna kulit, jenis kelamin, bahasa, politik, tingkat sosial-ekonomi, dan sebagainya. Tindakan diskriminatif tidak hanya keliru dan salah, tapi juga akan menimbulkan dan mempertahankan kondisi yang memudahkan penularan HIV/AIDS. Diskriminasi menciptakan suasana lingkungan yang menyulitkan perubahan perilaku dan menghambat masyarakat menanggulangi masalah HIV/AIDS.

Lapisan masyarakat yang menderita perlakuan diskriminatif sehingga memudahkan tertular HIV/AIDS antara lain perempuan, anakanak, masyarakat miskin, suku-suku terasing, kaum migran, penderita cacat, tahanan, pekerja seks dan pecandu narkotika. Komisi HAM Internasional menyatakan bahwa pemerintah tidak boleh melakukan diskriminasi terhadap orang dengan HIV/AIDS ataupun terhadap masyarakat yang mempunyai perilaku risiko tinggi tertular HIV. Odha perlu dilindungi hakhaknya di berbagai bidang, seperti di bidang lapangan kerja, perumahan, pendidikan, layanan hukum, layanan kesehatan, sosial dan kesejahteraan, serta di bidang asuransi.

Untuk menciptakan suasana di masyarakat yang mendukung persamaan hak odha di depan hukum dan mencegah timbulnya tindakan diskriminasi, pemerintah bersama-sama dengan masyarakat dan LSM perlu menyelenggarakan pendidikan dengan tujuan khusus menghilangkan diskriminasi terhadap odha. Masyarakat perlu dididik untuk bersikap wajar terhadap odha dan dimotivasi untuk menyelenggarakan program dukungan terhadap odha.

Kedua, hak atas kemerdekaan dan rasa aman. Tak seorang pun boleh ditangkap, dipenjara, diisolasi atau dipisahkan dari masyarakat, hanya karena ia terinfeksi HIV atau sakit AIDS. WHO menganjurkan agar odha tetap berada di tengah-tengah masyarakat. Di penjara 
pun, seorang tahanan yang terinfeksi HIV tidak boleh dipisahkan atau diisolasi dari tahanan lain.

Ketiga, hak untuk menikah. Odha mempunyai hak untuk menikah dan berkeluarga, dan untuk menghormati hak tersebut maka penyuluhan dan konseling seharusnya tersedia untuk odha dan pasangannya. Kita harus menghormati hak odha untuk hamil dan mempunyai anak. Sewaktu perempuan dengan HIV hamil dan ia ingin melanjutkan kehamilannya, maka bayinya juga mempunyai hak untuk dilahirkan normal tanpa cacat. Untuk melindungi hak bayi, termasuk untuk menghindarkannya dari penularan HIV dari ibunya, odha perempuan tersebut perlu mendapat layanan dan pengobatan sewaktu hamil, baik sewaktu melahirkan maupun sesudahnya.

Keempat, hak untuk mendapatkan pendidikan. Odha mempunyai hak untuk mendapatkan pendidikan. Pendidikan odha seharusnya tidak dibatasi, dan interaksi sosial di sekolah perlu dibina dengan baik agar odha tidak tersingkir. Jika ini ditegakkan, tidak perlu lagi ada anak yang ditolak atau dikeluarkan dari sekolah gara-gara status HIV-nya, apalagi hanya status HIV orangtuanya, seperti yang terjadi tahun 2012 lalu di Jakarta. Namun untuk dicatat kejadian ini tidak hanya di Indonesia, tetapi juga pernah terjadi di Amerika, ketika seorang odha harus berhenti dari sekolah karena protes beberapa orangtua siswa yang lain yang ketakutan anak-anaknya tertular HIV karena satu sekolah bersama siswa dengan HIV.

Kelima, HAM untuk perempuan berstatus odha. Diskriminasi terhadap perempuan, de facto dan de jure, memudahkan perempuan terinfeksi HIV. Subordinasi perempuan di dalam keluarga ataupun di masyarakat merupakan faktor penting yang menyebabkan peningkatan kecepatan infeksi HIV pada perempuan. Diskriminasi yang berlatar belakang ketimpangan gender juga menyulitkan perempuan sewaktu menghadapi konsekuensi infeksi HIV pada diri mereka, ataupun infeksi HIV pada anggota keluarganya.

Dalam kerangka upaya pencegahan infeksi HIV, seharusnya direalisasikan hak odha untuk mendapat informasi, pendidikan, dan layanan kesehatan. Dengan ketersediaan informasi pun, perempuan masih sulit untuk melakukan negosiasi dengan suami atau pasangan seksualnya mengenai seks yang lebih aman untuk mencegah penularan HIV. Hal ini disebabkan oleh subordinasi perempuan secara sosial dan seksual, serta ketergantungan perempuan di sektor ekonomi.

Saat ini masih dirasakan adanya miskonsepsi dalam penularan dan epidemiologi HIV/AIDS, yaitu adanya anggapan bahwa perempuan adalah vektor penyakit, sumber penularan terpenting dalam penularan. Akibatnya, perempuan dengan HIV/AIDS atau yang diduga terinfeksi HIV, mengalami berbagai tindakan kekerasan dan diskriminasi, baik di kehidupan pribadi maupun di masyarakat. Pekerja seks seringkali diharuskan diperiksa darahnya untuk tes HIV tanpa konseling. Kadang-kadang bahkan tanpa upaya penyuluhan kepada klien mereka untuk memakai kondom, dan juga tanpa upaya penyediaan layanan kesehatan yang memadai.

Keenam, HAM untuk odha anak. Telah disepakati secara internasional bahwa yang disebut anak adalah yang berusia kurang dari 18 tahun, kecuali undang-undang menentukan lain. Selain hak-hak yang secara khusus dibahas pada Konvensi Hak-hak Anak, sebagian besar hak anak adalah hak yang juga berlaku untuk orang dewasa, seperti hak untuk hidup, mendapatkan pendidikan, layanan kesehatan, perlakuan nondiskriminatif, hak berserikat, dan hak menyatakan pendapat. Hak-hak untuk bebas dari pelacuran, eksploitasi seksual dan kekerasan seksual amat relevan dengan program pencegahan penularan HIV.

Ketujuh, hak untuk bepergian. Odha mempunyai kebebasan untuk bepergian, dan seharusnya tidak boleh ada peraturan untuk membatasi seseorang bepergian hanya berdasarkan status HIV-nya, karena sama sekali tidak ada dasar ilmiahnya.

Kedelapan, hak untuk menyatakan pendapat. Setiap orang mempunyai hak untuk menyatakan pendapatnya. Dalam kaitan dengan hal tersebut, setiap orang berhak mendapatkan dan mencari informasi apa pun, termasuk informasi mengenai pencegahan, perawatan, dan dukungan dalam mengatasi penyakit infeksi HIV/AIDS.

Kesembilan, hak untuk berserikat. Deklarasi Universal mengenai HAM menyatakan bahwa setiap orang mempunyai kebebasan untuk berserikat secara damai. Dalam konteks HIV/AIDS, kebebasan berserikat merupakan hal yang penting sekali untuk melaksanakan advokasi, lobi, dan dukungan untuk odha. Odha perlu mendapat perlindungan dari perlakuan diskriminatif, baik langsung maupun tak langsung. 
Penulis merasakan bahwa dengan membahas HAM pada HIV/AIDS sebetulnya kita mengkaji hak asasi manusia secara hakiki dan universal. Dan sebenarnya kita sedang mengkaji masalah kemanusiaan secara umum, baik yang berhubungan maupun yang tidak ada kaitannya sama sekali dengan HIV/AIDS.

\section{Integrasi Perlindungan HAM dan Keberpihakan Jender}

Peningkatan kapasitas ODHA dan populasi kunci dalam hal advokasi kebijakan, advokasi keuangan, serta hal-hal lainnya yang mampu mendukung terwujudnya keterlibatan yang bermakna dari ODHA dan populasi kunci dalam peremcanaan program dan pengembangan kebijakan. Lahirnya serangkaian peraturan perundang-undangan yang menguatkan perlindungan Hak Asasi Manusia ODHA dan populasi kunci, terutama di tingkat provinsi dan kabupaten/kota. Peningkatan peraturan yang kondusif dalam melindungi kelompok masyarakat yang tidak terinfeksi HIV tetapi rentan terinfeksi karena kelemahan posisi ekonomi dan relasi jender mereka terhadap kelompok yang memiliki perilaku recklessly (seperti ibu rumah tangga dan pekerja seks perempuan) menjadi tantangan untuk ditegakkan. Hal ini menjadi bagian dari dikenalkannya intervesi secara struktural pada SRAN 2010-2014 tetapi masih sangat sedikit bentuk pelaksanaannya yang efektif di lapangan. Beberapa good practice yang langsung berkenaan dengan upaya ini perlu diterapkan secara bertahap sehingga faktor penentu sosial yang menghambat upaya pencegahan penularan HIV ini dapat diselesaikan pada periode SRAN 2015-2019. Telah cukup banyak tersedia kebijakan yang kondusif dan berkaitan dengan penanggulangan AIDS (lebih dari 100 kebijakan tingkat nasional yang tersedia saat ini), mekanisme implemenatsi adalah bagian yang perlu menjadi perhatian penting pada fase berikutnya dalam response terhadap penanggulangan AIDS, diperlukan mekanisme dan upaya yang lebih baik terhadap struktur dan budaya hukum sehingga tujuan dari kebijakan tersebut dapat terpenuhi.

Berdasarkan hasil observasi dan evaluasi atas pelaksaanaan kegiatan diperoleh hasil antara lain:

1. Mitra belum cukup mengerti dan memahami HIV-AIDS dan HAM serta aturan hukum didalamnya namun memiliki keinginan besar untuk mengetahui dan memahami tentang
HIV-AIDS dalam perspektif HAM serta aturan hukum didalamnya.

2. Pada kegiatan penyuluhan dan sosialisasi HIV-AIDS dalam perspektif HAM serta aturan didalamnya kepada mitra bertujuan agar lebih memahami akan betapa penting menjaga kesehatan dan pergaulan hidup yang sehat.

3. Pada akhirnya mitra paham sebab dan akibat HIV-AIDS yang berdampak langsung pada masa depan sebagai generasi penerus bangsa:

\section{Hasil Kegiatan \\ Perencanaan}

Kegiatan-kegiatan yang dilakukan pada tahap perencanaan bisa dideskripsikan sebagai berikut:

a. Pembahasan Program Kegiatan

Persiapan yang diawali dengan pembahasan program dan langkah-langkah kerja tim mulai dari pembagian tugas dan tanggungjawab masing-masing anggota tim sampai dengan persiapan administrasi dan perangkat pendukung. Kegiatan lain yang masuk dalam persiapan adalah melakukan koordinasi dengan kepaka sekolah untuk menyampaikan rencana pelaksanaan kegiatan PKM. Kegiatan pembahasan program ini dilaksanakan pada bulan April 2018. Pada kesempatan ini tim pelaksana bertemu dengan Lurah Kelurahan Taratara beserta perangkat kelurahan untuk meminta persetujuan tentang kegiatan PKM yang akan dilaksanakan. Setelah disetujui kemudian tim menjelaskan secara rinci maksud dan tujuan pelaksanaan PKM pada masyarakat petani cap tikus di kelurahan Taratara Kecamatan Tomohon Barat kota Tomohon.

b. Penyusunan Draft Instrumen

Persiapan selanjutnya secara bersama tim kerja menyusun draft instrumen yang akan digunakan sebagai acuan dalam menjaring informasi atau data akurat tentang permasalahan mendasar mitra. Kegiatan ini dilaksanakan pada bulan Mei 2018. Instrumen yang disusun mencakup identifikasi atau penjaringan informasi permasalahan mendasar yang harus dipahami secara bersama sebelum mengawali kegiatan PKM ini antara lain adalah mengidentifikasi dan mempertajam serta menganalisis kembali faktor-faktor penyebab kedua permasalahan pokok di atas, juga mendapatkan informasi dan persepsi para petani cap tikus di Kelurahan Taratara mengenai permasalahan dan akar permasalahan yang 
dihadapi serta program yang ditawarkan dan langkah yang akan dilakukan untuk mengatasi permasalahan terutama yang berkaitan dengan upaya mengatasi permasalahan banyaknya anak putus sekolah karena persoalan biaya. Hasil identifikasi tersebut di samping menjadi dasar penyusunan rencana kerja sekaligus sebagai landasan pelaksanaan kegiatan PKM.

c. Penyusunan Program Pelatihan

Berdasarkan hasil indentifikasi tentan permasalahan yang ada di lapangan selanjutnya disusun program pelatihan. Dalam kegiatan ini dilakukan pemantapan pemahaman atau penyamaan persepsi tentang program yang akan dijalankan oleh tim itu sendiri dengan kepala sekolah dan para guru serta persiapan dan pengadaan materi yang akan digunakan dalam pelaksanaan kegiatan PKM.

\section{Pelaksanaan Kegiatan}

Pelaksanaan kegiatan IbM dilaksanakan selama dua hari, yakni tanggal 12-13 Oktober 2018. Hari pertama, tanggal 12 Oktober kegiatan difokuskan pada pemberian materi tentang profil petani cap tikus dan permasalahannya. Kegaitan ini dihadiri oleh 24 orang petani cap tikus dan perangkat kelurahan. Untuk sesi pertama disajikan dan dijelaskan tentang profil petani cap tikus dan perhitungan hasil usaha per bulan. Setelah itu para peserta diberikan waktu untuk istirahat. Selanjutnya dalam sesi kedua dijelaskan tentang bagiamana cara mengatur keuangan serta bagaimana membentuk kelompok tani cap tikus yang bisa mewadahi kegiatan simpan pinjam anggota kelompok tersebut. Dalam kegiatan hari pertama ini para peserta kelihatan begitu antusias dalam mengikuti setiap materi yang disajikan.

Pelaksanaan kegiatan hari kedua dilaksanakan pada tanggal 13 Oktober 2018. Kegiatan PKM pada hari kedua difokuskan pada penjelasan dan penguatan tentang peran orang tua dalam pendidikan anak-anak terutama dalam rangkah melanjutkan pendidikan sampai ke jenjang perguruan tinggi, di samping itu dijelaskan pula tentang prosuder pendaftaran mahasiswa di Universitas Negeri Manado dan beasiswa yang tersedia untuk warga masyarakat yang kurang mampu.

\section{Observasi dan Evaluasi}

Kegiatan selanjutnya yang dilakukan tim PKM adalah melakukan observasi dan evaluasi. Observasi dilakukan tim terhadap seluruh proses kegiatan mencakup proses pemberian materi dan perhitungan anggaran pendapatan dan tabungan untuk uang kuliah anak. Hal-hal pokok lainnya yang diobservasi oleh teim adalah kendalakendala dan kesulitan-kesulitan yang dihadapi oleh para petani cap tikus dalam mengelolah keuangan dan permasalahan yang dihadapi ketika hendak memasukkan anak mereka ke perguruan tinggi.

Evaluasi dilakukan oleh tim terhadap bagaimana para petani cap tikus mengelolah keuangan mereka dan berapa besar dana yang mereka sisihkan untuk biaya pendidikan anakanak mereka. Evaluasi dilakukan dengan berdasarkan hasil observasi yang telah dilakukan oleh tim. Dari hasil evaluasi tersebut kemudian oleh tim diberikan masukan dan koreksi terhadap hal-hal yang dianggap masih kurang dipahami oleh para petani cap tikus.

\section{Refleksi}

Refleksi dalam kegiatan PKM pada masyarakat petani cap tikus di Kelurahan Taratara ini dilakukan dengan tujuan untuk mengetahui kelebihan dan kekurangan yang muncul dalam proses pelaksanaan kegaitan ini. Hal ini dilakukan untuk menemukan rekomendasi yang cocok bagi pengembangan kegiatan selanjutnya. Hasil refleksi menjadi penting, karena lewat refleksi hasil kegiatan, para guru menyadari kekurangan dan kelebihannya masing-masing dan berusaha memperbaiki dalam proses kegiatan selanjutnya.

\section{KESIMPULAN}

Berdasarkan hasil kegiatan pengabdian kepada masyarakat Ibu-ibu dan Remaja Putri Desa Pineleng Satu Timur tentang Preventif HIV-AIDS dalam Perspektif Hak Asasi Manusia, maka diperoleh kesimpulan sebagai berikut :

1. Kegiatan yang dilakukan sangat membantu mitra dalam menyelesaikan permasalahan mengenai pengetahuan dan pemahaman akan bahaya dampaknya HIV-AIDS, pemahaman mengenai Hak Asasi Manusia dan aturan hukum yang mengatur Hak Wanita dan Anak sebagai kelompok rentan yang dilindungi oleh negara.

2. Sosialisasi yang diberikan kepada mitra sangat membantu pengetahuan dan pemahaman akan pentingnya mengetahui bahaya akan dampaknya HIV-AIDS, Hak Asasi Manusia dan aturan hukum yang mengatur Hak Wanita dan Anak sebagai kelompok rentan yang wajib dilindungi oleh negara.

3. Mitra pada akhirnya mengerti dan memahami akan pentingnya mengetahui 
bahaya akan dampaknya HIV-AIDS, Hak Asasi Manusia dan aturan hukum yang mengatur Hak Wanita dan Anak sebagai kelompok rentan yang wajib dilindungi oleh negara..

\section{DAFTAR PUSTAKA}

Literatur :

Amiruddin, R. (2011). Epidemiologi Perencanaan \& Pelayanan Kesehatan. Makassar : Masagena Press.

Asa, Simplexius, dkk. (2009). Efektifitas Penerapan Peraturan Daerah Penanggulangan HIV-AIDS (www.aidsindonesia.or.id/download/PE RDA-HIV-UNDANA.pdf).

Adi Santika, S. A. (2012). Review terhadap Peraturan Perundang-undangan terkait Penanggulangan HIV dan AIDS.

Ariawan, I. (2013). Analisis Situasi Epidemi $H I V$ di Indonesia. Universitas Indonesia, KPAN.

Badan Narkotika Nasional, Pusat Penelitian Kesehatan Universitas Indonesia. (2011). Survei Nasional Perkembangan Penyalahgunaan dan Peredaran Gelap Narkoba pada Kelompok Pelajar dan Mahasiswa di Indonesia.

BKKBN. (2013). Pencegahan Masalah Kesehatan Reproduksi, Kumpulan Booklet Materi KIE (Intervention in Reproductive Health).

BKKBN. (2013). Petunjuk Pelaksanaan Peningkatan Pemakaian Kondom Dual Proteksi.

BKKBN. (2013). Siklus Hidup Kesehatan Reproduksi Manusia, Panduang Materi Pengelola Programme KB.

Direktorat Jenderal Bina Gizi dan Kesehatan Ibu-Anak, Direktorat Bina Kesehatan Ibu, Kementerian Kesehatan. (2013). Rencana Aksi PPIA Tahun 2013-2017.

Ditjen PP \& PL Kemenkes RI. 2011. Statistik Kasus HIV AIDS di Indonesia.
Indar. (2010). Etika dan Hukum Kesehatan. Makassar : Lembaga Penerbitan Universitas Hasanuddin (Lephas).

Ikatan Perempuan Positif Indonesia. (2013). Kasus Kekerasan terhadap Perempuan dengan HIV \& AIDS di 3 Provinsi.

Ikatan Perempuan Positif Indonesia. (2011). Kualitas dan Rekomendasi Perbaikan Layanan PPIA bagi Perempuan terinfeksi HIV di 4 kota di Indonesia.

Ikatan Perempuan Positif Indonesia. (2010). Kualitas dan Rekomendasi Perbaikan Layanan PPIA bagi perempuan terinfeksi HIV di Empat kota di Indonesia.

Kementerian Hukum dan Hak Asasi Manusia, Direktorat Pemasyarakatan. (2010). Prevalensi HIV dan Sifilis dan Studi Perilaku Berisiko pada Narapidana di Lapas dan Pusat Penahanan di Indonesia.

Kementerian Kesehatan. (2011). Survei Cepat Pengetahuan Komprehensif HIV di 5 Kota di 5 Provinsi.

Kementerian Kesehatan. (2012). Estimasi Besar Populasi Kunci HIV and Orang Dengan HIV dan AIDS (ODHA) 2012.

Kementerian Kesehatan. (2013). Rencana Aksi Percepatan Penurunan Angka Kematian Ibu di Indonesia. Direktorat Jenderal Bina Gizi dan Kesehatan IbuAnak, Direktorat Bina Kesehatan Ibu.

KPAN, UNAIDS. (2012). Briefing Note: Respon Masyarakat terhadap HIV dan AIDS.

KPAN, UNAIDS. (2012). Ringkasan Penggagas dan Kelompok Dukungan untuk ODHA.

KPAN, (2015). Penanggulangan HIV AIDS Di Indonesia. Strategi Dan Rencana Aksi Nasional 2015-2019.

Lubis, Todung Mulya. (2007). HIV-AIDS dan Hak Asasi Manusia : Sebuah 
EDUPRENEUR || Vol. 2, No 2, Juli 2019

Jurnal Pengabdian Kepada Masyarakat Bidang Kewirausahaan

Catatan

(http://www.kesrepro.info/?q=node/303)

(www.scribd.com/doc/46156309/PERLI

NDUNGAN-HUKUM).

Yayasan Spiritia. (2008). Strategi Nasional

Penanggulangan HIV-AIDS 2003-2007.

Yendi. Perlindungan Hukum Bagi Penderita

HIV-AIDS dan Tenaga Kesehatan 